\title{
The Client Capital in Nursing Management in Hospitals ${ }^{a}$ \\ O Capital do Cliente na Gestão de Enfermagem em Hospitais \\ El capital del cliente en la Gestión de Enfermería en Hospitales
}

Ana Lúcia Arcanjo Oliveira Cordeiro ${ }^{1}($ (D) Josicélia Dumêt Fernandes ${ }^{1}$ (iD Maria Deolinda Antunes Luz Lopes Dias

\section{Mauricio ${ }^{2}(1)$}

Rosana Maria de Oliveira Silva ${ }^{1}$ (I) Cláudia Silva Marinho Antunes Barros ${ }^{1}$ (I) Cátia Maria Costa Romano ${ }^{1}$ (iD)

1. Universidade Federal da Bahia.

Salvador, BA, Brasil.

2. Escola Superior de Enfermagem de Lisboa. Lisboa, Portugal.
Corresponding author:

Ana Lúcia Arcanjo Oliveira Cordeiro.

E-mail: anaarcanjo@hotmail.com

Submitted on $04 / 24 / 2019$

Accepted on 08/12/2019.

DOI: 10.1590/2177-9465-EAN-2019-0123

\begin{abstract}
Objective: To analyze how the components of the client's capital are used in the management of nursing in hospitals. Method: A qualitative research carried out in five public hospitals, four private hospitals and three philanthropic hospitals in the period from October 2014 to May 2015. Data were collected through a semi-structured interview with twelve nursing managers and analyzed according to content analysis. Results: The components of the Client's Capital were used by the nurses when performing the management of the client service to promote changes and improve the service after evaluating the satisfaction of the nursing care through active systematic search, with its own evaluation tools and the ombudsman's information and in the interaction with suppliers of materials, equipment and services. Conclusion and implications for practice: The managers use managerial actions for the development of the client's capital of organizations. In order to improve them, they must evaluate the nursing care in a continuous and strategic process to satisfy the clients, throughout their trajectory in the organization, since clients are permanent sources of innovation that affect professional and organizational development and productivity.
\end{abstract}

Keywords: Nursing Services; Management; Patient's satisfaction; Client.

\section{RESUMO}

Objetivo: Analisar como os componentes do capital do cliente são utilizados na gestão da enfermagem em hospitais. Método: Pesquisa qualitativa, realizada em quatro hospitais privados, cinco hospitais públicos e três hospitais filantrópicos, de outubro de 2014 a maio de 2015. Os dados foram coletados através de entrevista semiestruturada com 12 gestoras de enfermagem e analisados segundo a análise de conteúdo. Resultados: Os componentes do Capital do Cliente foram utilizados pelas enfermeiras ao realizar a gestão do atendimento ao cliente para promover mudanças e aprimorar o serviço após realizar a avaliação da satisfação do atendimento de enfermagem através de busca ativa, sistemática, com instrumentos de avaliação próprios e informações da Ouvidoria e na interação com fornecedores de materiais, equipamentos e serviços. Conclusão e implicação para a prática: As gestoras utilizam ações gerenciais para o desenvolvimento do capital do cliente das organizações. Para aperfeiçoá-las, devem avaliar o atendimento de enfermagem em processo contínuo e estratégico para satisfazer os clientes, durante toda a sua trajetória na organização, uma vez que clientes são fontes permanentes de inovação que geram impacto no desenvolvimento e produtividade profissional e organizacional.

Palavras-chave: Serviços de Enfermagem; Gerência; Satisfação do paciente; Cliente.

\section{Resumen}

Objetivo: Analizar cómo se utilizan los componentes de capital del cliente en la gestión de enfermería hospitalaria. Método: Investigación cualitativa, realizada en cuatro hospitales privados, cinco hospitales públicos y tres hospitales filantrópicos, de octubre de 2014 a mayo de 2015. Los datos fueron recolectados a través de entrevista semiestructurada con 12 gestoras de enfermería y analizados según el análisis de contenido. Resultados: Los componentes del Capital del Cliente fueron utilizados por las enfermeras al realizar la gestión de la atención al cliente para promover cambios y mejorar el servicio después de realizar la evaluación de la satisfacción de la atención de enfermería a través de búsqueda activa, sistemática, con instrumentos de evaluación propios e informaciones de la Oidoría y en la interacción con proveedores de materiales, equipos y servicios. Conclusión e implicaciones para la práctica: Las gestoras utilizan acciones gerenciales para el desarrollo del capital del cliente de las organizaciones. Para perfeccionarlas, deben evaluar la atención de enfermería en proceso continuo y estratégico para satisfacer a los clientes durante toda su trayectoria en la organización, una vez que los clientes son fuentes permanentes de innovación que generan impacto en el desarrollo y productividad profesional y organizacional.

Palabras clave: Servicios de Enfermería; Administración; Satisfacción del paciente; Cliente. 


\section{INTRODUCTION}

Client Capital (CC), also known as Relational Capital $(\mathrm{RC})$, is an element that forms the Intellectual Capital (IC) in organizations and refers to their relationship with their clients and suppliers, using various forms of internal and external interaction, evidenced more effectively, when there is a demonstration of the value that has a network of satisfied clients. ${ }^{1,2}$ In this study, in defining the theoretical framework we name the patient/user of the hospital network as client, as it is the most important element of the Intellectual Capital of an organization. For he/she is the one who uses and pays for the service, whether in the private or public sector. ${ }^{3}$

In this sense, CC management in organizations should be directed towards customer satisfaction with actions involving the components: client retention; acquisition of a new customer; client support; client driven innovation; relationship; communication; complaints; trust; quick response and company image. ${ }^{1}$

These components, in the context of hospital organizations, are experienced differently from other organizations, because the health area is influenced by the political and social system of the country, whose production planning should consider it as a company that takes care of human life, ${ }^{4}$ but also needs to adopt good management practices oriented towards the efficiency in its core business. ${ }^{5}$ Thus, strategies for Client Capture and Retention are limited, especially in the public sector, which often has to extrapolate its service ability in the face of increasing population demands.

Therefore, in the private sector, it is clear the influence of the political and social context in view of the dependence of the resources contracted on health plans. However, even if these aspects are restrictive, they make it possible for clients to choose from limited options, considering the reference of the adequate meeting of their needs and expectations, which enables them to increase their level of satisfaction and loyalty to the organization. ${ }^{6}$

In this understanding, the satisfied client promotes the positive image of the organization, increases loyalty, with consequent increase in competitiveness, growth and organizational development. ${ }^{7}$

It is known that the client/user/patient is the reason for the existence of nursing, whose care is the essence of its practice being associated with relationships with the family, other health professionals and with service providers and inputs. The relationship with suppliers also builds the $\mathrm{CC}$ of an organization by being an ally that ensures the continuity and development of processes. $^{7}$

Therefore, for nursing, meeting clients' needs involves intra and extra organizational relationships, highlighting that the care process requires uninterrupted actions to evaluate the quality of service provided and customer satisfaction. In this sense, the assessment should be continuous and procedural, focused on client appreciation and on the competence of all professionals, and consequently meeting implicit and explicit needs, reducing complaints, promoting a pleasant environment and empathetic relationships that favor the client to manifest his/her desires. ${ }^{1}$

Considering that the quality of the organization's relations with clients and suppliers has repercussions on the CC, and that the management process has been influenced by scientific, technological, information and population demands, it became relevant to question: How are the CC's components used in hospital nursing management? The study aimed to analyze how the client capital components are used in nursing management in hospitals.

\section{METHOD}

This is a qualitative study, which analyzed the reports of nursing managers working in nine hospitals in the city of Salvador, northeastern Brazil, about their experiences in using the $\mathrm{CC}$ in professional practice. Thirty-two nurses were selected to participate in the study because they held the management position of the 32 medium and large hospital organizations in Salvador-Bahia. Data collection took place from October 2014 to May 2015 and no male was found occupying a management position. Nine hospitals that authorized the research were included: three public, five private and one philanthropic. After the identification and location of the managers, contacts were made with them by means of the presentation of the researchers and the research project and the invitations were sent through e-mail and social networks, whose content explained the research intent, objectives and importance of the participation in the study. Of these selected nurses, 12 did not respond; two were not available to participate; two were on vacation; one on maternity leave; and three were awaiting advice from the hospital's research committee for participation, which received no answers.

Twelve interviews were conducted with nurse managers, following the criterion of exhaustion of information, to finalize the search for participants, five from public hospitals, four from private hospitals and three from philanthropic hospitals, which managed nursing services, such as managers, coordinators, directors and advisors, who had been in office for at least 6 months, understanding that, after this period in office, they were already integrated into the organization, more secure in the management process regarding the formulation of institutional policies. Were excluded managers on vacation or leave. The average time in management ranged from 5.8 to 10 years.

The interview script consisted of two parts, the first with sociodemographic information; and the second, with the following question: Describe to me how you use the following client capital components in management practice: client acquisition and retention, customer satisfaction, and the partnership/integration system. During the process, the researcher needed to clarify doubts regarding the terms, when necessary, to respond to the purposes of the study, thus facilitating the flow of reports. 
The interviews were recorded with the permission of the participants, using the voice recorder program installed on the cell phone of the first author, teacher and doctoral student, who conducted the interview, in order to record all the information provided. These interviews lasted an average of 30 minutes and were conducted individually, in a silent, exclusive room and without interruptions at the place of choice of the interviewees. At the end of the interview, the participants had the opportunity to listen to the recordings to authorize the transcription.

The analyzed data, according to the Content Analysis, followed three steps: pre-analysis, material exploration and data processing. ${ }^{8}$ In the first stage, the content of the interviews was superficially read in order to come to the constitution of the corpus. Later, in the second, the completeness was obeyed, determined by the use of all the content of the interviews, the representativeness to express the components of the $E C$, and the homogeneity of the interviews, seeking their similarities and the relevance of the content to the research objectives. Subsequently, clipping, decomposition, coding and assignment of the unit of enumeration of the record units or theme were performed, which, by similarity, were grouped into one category and two subcategories for information organization and analysis. The data saturation point was reached when the information began to repeat without new elements being identified in the analysis category. The third and last stage of Content Analysis is performed by interpreting the results and synthesizing the analysis.

The study approved under Opinion No. 812.679/2014, CAAE 36373614.3.0000.0048 met the guidelines and standards governing research involving human subjects, precepted by Resolution 466/2012 of the National Health Council and follows the consolidated criteria for qualitative research reports. (COREQ). ${ }^{9}$

After hearing the necessary clarifications, the participants agreed to sign the Informed Consent Form in two copies, one of which was given to the interviewed nurse and the other kept with the researcher. To preserve the identity of the managers, the alphanumeric system $\mathrm{M}$, for manager, was used, followed by the number, according to the order of the interviews, from M1 to M12.

\section{RESULTS}

The 12 interviewees were female, held general administration positions of the nursing service, which received names according to the hospital's administrative organization: management, coordination, board and advisory. The time in these positions ranged from one and a half to 20 years, time since graduation ranged from 8 years to 40 years; all with postgraduate level of specialization in management, two with a master's degree and one with a doctorate; the time of admission to the organization ranged from 6 to 35 years. These individual characteristics of the interviewed managers facilitated the understanding of their reports considering the context to which they are linked, and their experiences and qualifications for the position.
Participants used the formative elements of intellectual capital: human capital, structural capital and client capital, during the management of nursing service activities, which were presented and analyzed in the thesis report: Intellectual Capital in Nursing Care Management in Hospital Organizations, ${ }^{a}$ defended by the first author, in 2015, at the Nursing School of the Federal University of Bahia, from which clippings were made that individually analyzed the categories People Management and Management of Operational Processes, referring to human capital and structural capital, respectively. ${ }^{10,11}$

For this study, we extracted from this thesis, for analysis, the contents related to client capital and the category Client Service Management. It was found that for customer service, in nursing service, a set of management actions is performed to assess client satisfaction and improve the relationship with external suppliers.

The assessment of client satisfaction was performed in nursing services by managers, using an assessment tool, active and systematic search and data from the ombudsman, which resulted in changes, improvement and the development of best practices in nursing care:

[...]One thing I am always looking into is client satisfaction.I work precisely to ensure that the care process is well done, including, enabling conditions that the hospital can serve this client, working indirectly, but seeking client satisfaction [...] how he/she verbalizes us in the Ombudsman's data and in the client satisfaction survey data (M8).

We do a whole job focused on client satisfaction [...] when the client leaves he/she fills out a satisfaction report, evaluating the service; so this bulletin comes to us and we take it to HR [...] sometimes, when the patient suggests, we implant and call him/her to say that we implemented that suggestion he/she had given (M11).

Measuring client satisfaction about nursing services is performed using own forms, prepared by nurses:

We also built these client satisfaction forms, and they were very active, applied to all patients admitted and evaluated to guide conducts in the service [...] (M1).

We have a user satisfaction survey for the entire hospital [...] one of the services that is evaluated is the Nursing Service (M3).

The use of active search and ombudsman data to assess client satisfaction were cited:

We have the evaluation research, we have a visit, which are the active searches; We make the visits in the rooms because the client only takes the form to say that he/she 
is dissatisfied; so we have this other way of also seeking this assessment... (M4).

We also measure client satisfaction. I started an active search, doing the opposite service; she [responsible person] was going to guide clients, how important they were to express themselves through opinion (M2).

We have the Ombudsman's Office, which is one of the tools we use to evaluate and classify the satisfaction's assessments [...] The Ombudsman, whatsoever the clients' as for from the professionals'; so I get compliments and criticism from both the service and the professionals (M9).

The Ombudsman here [...] is for clients and also employees who are dissatisfied with some things; the Ombudsman brings here and I call the coordinator [...] there are many people here who praise and cite the person's name (M10).

The use of information serves as a reference for the development of best practices in nursing care, as excerpts:

[...] The issue of client satisfaction, they bring a lot of information and from it you also change a lot, but we grow, we transform and make the change [...] client satisfaction is one of the elements of change that always causes it. We stimulate patients to evaluate the service (M5).

We have a very proactive work. I do not expect the client to file a complaint; I try to visit that client; we encourage this daily visit [...] I try to know what we need to improve to meet his/her satisfaction, and with that we have, I believe, greatly improved the issue of client satisfaction [...] (M6).

The relationship with suppliers of products and services is a reality of managers for the acquisition of essential materials, equipment and services, which contribute to the implementation of nursing care conducts, as excerpts:

Nursing is a reference for the purchase of materials and equipment for care and for the problem solving of administrative issues and implementation of conducts (M1).

The supplier does not have access to the care area it is directly with the management [...] the access flow of new devices goes through various viability processes and starts with the nurse manager (M4).

We have services provided by third parties, cleaning, sterilization of special materials and payroll suppliers, for example (M12).

\section{DISCUSSION}

In managing client capital, the managers of this study report developing actions aimed at managing client service and relationships with external suppliers, for service development and best care practices.

Evaluative actions implemented in the service to identify the level of client satisfaction using their own assessment instrument were reported by the managers, whose data served as a reference for the development of service improvements. In this context, in the perspective of health organizations, as in other business segments, the implementation of quality of service assessment practices, client-centered, using instruments to measure their satisfaction, has been growing, both in the public and private sectors, in many countries around the world, especially in developing countries such as Turkey, India, Saudi Arabia, and Brazil. ${ }^{12-15}$

In Brazil, the incipient culture of evaluating the results of healthcare services can still be considered fragile, since auditing, being the most used, is focused on costs and financial aspects, although some changes have been occurring in this context, with hospital accreditation, where it is necessary to implement and maintain certain quality standards in the result of the service, such as client satisfaction. ${ }^{16}$ These aspects, allied to the understanding that the nurse manager should direct their actions to make them compatible with the organizational objectives and client needs, with view to improving nursing care, will promote both professional and organizational growth. ${ }^{17}$ Thus, the actions reported by the nurses interviewed in this study reiterate conceptions that clients and suppliers of products and services are partners and contributors, sources of development and innovation. ${ }^{7}$

A study that analyzed the difference between the customer who buys the healthcare service and another who is a business customer focused on the meaning of health care and assistance in a complex system such as the hospital, recommending that these organizations recognize that each component of the system involved in health care service depends on all other parties to achieve mutual goals and, still, to satisfy the patient, the service must conduct research to know what really matters to them. ${ }^{18}$

In assessing customer satisfaction, the managers used their own assessment tools, which served as a reference for the development of best practices in nursing care. Study has highlighted the impact of patient satisfaction assessment on improving quality of care by pointing this assessment as a tool that provides opportunities to improve strategic decision making, reduce costs for effective management, monitor health plan performance and meet expectations of patients. ${ }^{17}$

Meeting the needs and expectations of patients is part of quality management, raising the level of patient satisfaction 
and loyalty, proves study held in Iranian private hospitals. ${ }^{6}$ The managers interviewed in this study agree with these results, showing concern by making efforts to enable customer service conditions focused on satisfaction in the hospital environment. However, it should be noted that satisfying the client, due to the complexity of the health sector, is a challenge, as it involves details of their experience in the service, which depend on professional expertise in the nursing service, and their relationships with other health professionals of this area, which often are influenced by the organizational environment, collective skills and precarious work, among others.

The study discusses challenges for measuring patient experience and satisfaction, noting that these direct and indirect experiences of the patient with the health care system are based on many factors experienced before, during and after a care episode. Thus, they may not be linked to the quality of care received, but to their expectations of prognosis, treatment, family interaction and environment. ${ }^{19}$

A survey with 422 patients in a US hospital proves that measuring patient satisfaction is important in health care, but should not be used as an indicator of overall quality, safety or effectiveness of treatment. ${ }^{20} \mathrm{It}$ is noteworthy that the results of studies on quality assessment of hospital service brings important knowledge about expectations, perception and client satisfaction. In India, a study found that tangibility, reliability, responsiveness, assurance, courtesy, and empathy are important aspects for producing satisfied customers. ${ }^{13} \mathrm{~A}$ study with 380 patients from private hospitals in Pakistan found empathy and safety as the most important elements in patient satisfaction. ${ }^{21}$ In the same country, another survey with 611 patients added the welcoming and physical environment, communication, and privacy as impacting on patient satisfaction and loyalty to the hospital. ${ }^{22}$

It is notorious that in the context of hospital organizations the quality of nursing services affects client satisfaction in relation to the organization as a whole. The relationship between nursing working conditions and patient satisfaction was evaluated in 430 hospitals and it was concluded that in hospitals where nurses work with better working conditions, such as lower workload, lower patient/nurse ratio and higher remuneration and experience levels, client satisfaction was higher. ${ }^{23}$

The dialogical process, integration and partnership with customer and suppliers are important for the productive process in the organization. Customer integration enables you to understand what you expect and value in service, helps you identify expressed and unexpressed needs, and what services are important for attending him/her.

The managers reported using the active search to perform an individualized service, to obtain information or complaints and make changes, restructuring and innovation in the service, and also reported to perform the service evaluation when the client is discharged and the implementation of changes in service. This assessment produces guidelines to improve service, however, must be performed throughout the process, even before the client's admission, acquisition or use of services. In this understanding, hospital organizations need to understand that assessing satisfaction and listening to complaints are the most effective means for clients to provide ways to improve the care provided. ${ }^{24}$

Assessing client service and satisfaction, similar to companies in other segments that need to retain their clients, should be valued in healthcare organizations because they provide and sell complex services that, in most cases, the client spontaneously would not like to receive or are undesirable due to illness, need for recovery of their health or maintenance of life. ${ }^{3}$ In this aspect, it can be inferred that even if they do not wish to return to the hospital, the satisfied client is a source of referral to other clients and to the positive image of the organization thus highlighting its social mission in the health system.

Despite the differentiated reality of healthcare organizations, regarding the option of maintaining client loyalty, it is important to point out the study that found that the cost of retaining a client, being several times lower than the cost of attracting new ones, therefore, it is reiterated that the organization's ability to identify and meet clients needs and maintain effective client relationship and information system management increases their loyalty. ${ }^{25}$ For these reasons, organizations should be aware of the client perception and expectations, and frequently analyze the results of this assessment, as they have the power to determine how well a product or service meets their needs and expectations. ${ }^{7}$

When the service is focused on the client, it must have objectives that meet his/her expectations, translated into important needs that are sometimes not spelled out. However, the more the client is known, the more evident their expectations become, enabling improvement strategies that are favorable to client loyalty. ${ }^{26}$ Customer satisfaction is part of quality standards in all processes and services offered and must meet and exceed their desires or enchant them. ${ }^{24}$ Studies that assessed satisfaction in public service attendance found fragility of humanization of care due to deficiencies in reception and communication, contributing to client dissatisfaction. ${ }^{14,15,22}$ Thus, it was evident that the client's wishes, which are considered obvious or even elementary, should not be neglected, since the non-fulfillment of these wishes may trigger dissatisfaction and compromise the quality of care.

The managers reported using assessment tools such as the questionnaire, developed by them and applied through visits to the inpatient units and also the data form provided by the Ombudsman, to investigate client satisfaction in relation to nursing care. However, there are already validated and more complete evaluation models for the nursing service, which are available and can be adapted according to the organizational context.

Satisfaction survey using a validated instrument of the Brazilian version of the Patient Satisfaction Instrument (PSI) allowed the identification of potentialities and disabilities in the 
studied hospital, providing subsidies for the reorganization of care, management and teaching activities. ${ }^{27}$ Another study, applying the same instrument concluded that nursing care generally meets the expectations of patients. However, there were biases regarding this result, such as the difficulty of users' access to services, which may influence the service to be considered satisfactory due to the fact that it has been achieved, disregarding deficiencies. ${ }^{28}$

In another experience of adaptation and validation of The Satisfaction with Decision Scale (SWD), the authors concluded that patient satisfaction has been important in nursing care assessment, in the quality of the decision making process and the impact of interventions. ${ }^{29}$

Several models of questionnaires and ways to assess client satisfaction in health care are disseminated internationally, such as the model used in Vietnam with 26 assessment items involving six aspects: access and admission, general patient information, treatment and related information, complaints management, physical environment and follow-up..$^{30} \mathrm{~A}$ study in China proposed an evaluation model and found that patient satisfaction was significantly affected by perceived quality, expectation and impact of the disease, hospital referral, and client complaints. ${ }^{31}$

In validated instruments for the evaluation of client service satisfaction, with possibilities of adaptations, attention should be paid to the inclusion of elements focused on the evaluation of the experiences lived by them in the service situation, such as the form of reception; information and guidance received; trajectory through the various sectors; agility and resolution of the problems that led customers to the organization.

The public hospital managers participating in this study reported using the Ombudsman information to identify customer complaints or dissatisfaction and implement improvements in care. In this sense, when effective, the demands generated in this process promote changes in organizations, whether public or private, especially when assessing the level of trust, acceptance and identification of requirements and expectations of performance and of services offered, ${ }^{32-35}$ however it is known that data collected when the patient has left or is leaving the hospital prevents immediate effective actions to improve that care. It is recommended, therefore, that the assessment of client satisfaction should not be limited to the time of discharge or complaints to the Ombudsman, but rather before, during and after nursing care.

The managers reported the relationship with the hospital's external suppliers, especially when the purchase of products and equipment occurs and when there are outsourced service providers, with the effective participation of the nursing manager who monitors and evaluates these services in public and private hospitals.

It is known that in nursing the relationship with external suppliers is historical, due to the managerial actions of structuring the environment, predicting and providing resources for the operationalization of care. Currently, in many hospitals, there are services organized specifically for this purpose, but the nurse continues to participate in this process, being part of the team that develops these activities. ${ }^{36}$

In the understanding of the $\mathrm{CC}$, there was a consensus that suppliers are partners and potential clients, positively influencing innovation and changes in organizational structure. The efficiency of the supply sector depends on establishing credible, reliable and accessible business relationships between buyer and supplier. ${ }^{37,38}$

In the context of the public service, in which bidding and electronic trading are the means used for the acquisition of consumable and permanent materials, nursing practice occurs in determining the type of material to be purchased for the service units, standardization and technical specification, control of quality of materials and technical advice that contribute to organizational decision-making regarding the adoption or discontinuation of the acquisition of certain materials and equipment and the qualification of suppliers. ${ }^{36}$

In this sense, the integration of nursing with suppliers that are part of the service relations network occurs more directly with outsourced service providers, maintenance services and during the evaluation of consumables or permanent resources. Thus, it is understood that the role of the supplier to deliver the resources rationally, efficient and necessary services for safe and quality care in the hospital, depends on the nursing work which provides information, descriptions and evaluations of client needs and service, in a process of effective interaction.

Given the aspects presented in this study involving client capital management as an important element to leverage organizational and professional development, it is worth mentioning the study that proved, in dermatological medical service, that losing client due to dissatisfaction of care resulted in important financial consequences for the organization and for professionals. ${ }^{39}$

Limitations in this study are the impossibility of generalizing the results to other hospital organizations because they are experiences of managers who work in certain contexts. However, these are experiences that can serve as a reference for other management scenarios of nursing.

\section{CONCLUSION AND IMPLICATIONS FOR PRACTICE}

The managers used the components of the CC: client acquisition and retention, client satisfaction, partnership/ integration system, when performing client service management through necessary management actions to assess nursing care satisfaction through active and systematic search and using assessment tools applied by them, as well as information from the Ombudsman sector and interaction with suppliers of materials, equipment and outsourced services to promote changes and improvement of the service. 
However, for these practices to be effective in the development of the $\mathrm{CC}$, nursing care assessments must be a continuous and strategic process that involves articulated actions to better meet needs and satisfy clients throughout their trajectory in the organization, and should not be limited to the moment of discharge or complaints to the Ombudsman.

This study is expected to contribute to nurses' knowledge of $\mathrm{CC}$ in management practice and to provide understanding of the potential of the client/patient/user and suppliers as indispensable sources of information for the evaluation and establishment of care quality improvement strategies, professional development and achievement of organizational results.

\section{FINANCIAL SUPPORT}

The present work was carried out with support of the Coordination for the Improvement of Higher Education Personnel - Brazil ("CAPES") - Institutional PhD Sandwich Program Abroad ("PDSE") through a grant awarded to Ana Lúcia Arcanjo Oliveira Cordeiro held at the Lisbon Nursing School, Portugal, from November 2014 to January 2015.

\section{REFERENCES}

1. Stewart T. A riqueza do conhecimento: o capital intelectual e a organização do século XXI. Rio de Janeiro: Campus; 2002.

2. Núñez PIA, Núñez GY. Propuesta de clasificación de las herramientas software para la gestión del conocimiento. ACIMED [Internet]. $2005 \mathrm{apr}$ [cited 2017 oct 06]; 13(2):1-34. Available from: https://dialnet.unirioja. es/servlet/articulo?codigo=1418044\&info=resumen\&idioma=SPA

3. Saito DYT, Zoboli ELCP, Schveitzer MC, Maeda ST. Usuário, cliente ou paciente? Qual o termo mais utilizado pelos estudantes de enfermagem? Texto Contexto - Enferm [Internet]. 2013 mar; [cited 2017 oct 06]; 22(1):175-83. Available from: http://www.scielo.br/scielo. php?pid=S0104-07072013000100021\&script=sci_arttext\&tlng=pt DOI: http://dx.doi.org/10.1590/S0104-07072013000100021

4. Littike D, Sodré F. The art of improvisation: the working process of administrators at a Federal University Hospital. Ciênc Saúde Coletiva [Internet]. 2015 oct; [cited 2019 jun 06]; 20(10):3051-62. Available from: http://www.scielo.br/scielo.php?script=sci_arttext\&pid=S1413$81232015001003051 \&$ Ing=pt\&nrm=iso\&tlng=en DOI: http://dx.doi. org/10.1590/1413-812320152010.00042015

5. Farias DC, Araujo FO. Hospital management in Brazil: a review of the literature with a view toenhance administrative practices in hospitals. Ciênc Saúde Coletiva [Internet]. 2017 jun; [cited 2019 jun 01]; 22(6):1895-904. Available from: http://www.scielo.br/scielo. php?script=sci_arttext\&pid=S1413-81232017002601895\&lng=pt DOI: http://dx.doi.org/10.1590/1413-81232017226.26432016

6. Sadeh E. Interrelationships among quality enablers, service quality, patients' satisfaction and loyalty in hospitals. The TQM Journal [Internet] 2017 jan; [cited 2019 may 28]; 29(1):101-17. Available from: https:// www.emeraldinsight.com/doi/pdfplus/10.1108/TQM-02-2015-0032 DOI: http://dx.doi.org/10.1108/TQM-02-2015-0032

7. Stewart T. Capital Intelectual - a nova vantagem competitiva das empresas [Internet]. $2^{\text {a }}$ ed. Rio de Janeiro: Campus; 1998; [cited 2017 oct 09]. Available from: http://portaldeperiodicos.eci.ufmg.br/index.php/ $\mathrm{pci} /$ article/view/73

8. Bardin L. Análise de Conteúdo: a visão de Laurence Bardin. São Paulo: Edições 70; 2011.
9. Tong A, Sainsbury P, Craig J. Consolidated criteria for reporting qualitative research (COREQ): a 32-item checklist for interviews and focus groups. Int J Qual Health Care [Internet]. 2007 Dec; [cited 2019 mai 30]; 19(6):349-357. Available from: https://academic.oup.com/ intqhc/article/19/6/349/1791966 DOI: http://dx.doi.org/10.1093/intghc/ mzm042

10. Cordeiro ALAO, Fernandes JD, Maurício MDALLD, Silva RMO, Barros CSMA, Romano CMC. Human capital in the nursing management of hospitals. Rev Esc Enferm USP [Internet]. 2017; [cited 2019 aug 08]; 51:e03232. Available from: http://dx.doi.org/10.1590/S1980220X2016030203232

11. Cordeiro ALAO, Fernandes JD, Maurício MDALLD, Silva RMO, Barros CSMA, Romano CMC. Capital estrutural na gestão das enfermeiras em hospitais. Texto Contexto - Enferm. [Internet]. 2018; [cited 2019 aug 09]; 27(2):e4880016. Available from: http://www.scielo.br/scielo. php?script=sci_arttext\&pid=S0104-07072018000200328\&Ing=pt DOI: http://dx.doi.org/10.1590/0104-07072018004880016

12. Büyükdoğan $B$, Gedđk H, Derelđi $Y$, Tanyelđ $O$. The impact of service quality and public relations on patient satisfaction in hospitals. Electr J Social Sci [Internet]. 2017 jan; [cited 2017 jun 06]; 16(60):186-97. Available from: https://dergipark.org.tr/download/article-file/273124

13. Sathish AS, Indradevi R, Gangineni $S$. A service quality and its influence on customer satisfaction in a multi-speciality hospital. IJRTE [Internet] 2018 dec; [cited 2019 may 31]; 7(4S2):356-59. Available from: https:// www.ijrte.org/wp-content/uploads/papers/v7i4s2/Es2081017519.pdf

14. Owaidh AO, Atiah AA, Abadi AS, Ali AM, Abdullah AM, Abdullah AA Hassan AM. Patients' Satisfaction with Health Care Services in Southern Saudi Arabia. Egypt J Hosp Med [Internet]. 2018 jul; [cited 2019 may 30]; 72(1):3857-60. Available from: http://egyptianjournal.xyz/721_30. pdf DOI: http://dx.doi.org/10.12816/0047757

15. Gomide MFS, Pinto IC, Bulgarelli AF, Santos ALP, Gallardo MPS. User satisfaction with primary health care: an analysis of access and care. Interface (Botucatu) [Internet]. 2018 apr; [cited 2019 mai 30];22(65):38798. Available from: http://dx.doi.org/10.1590/1807-57622016.0633

16. Lorenzetti J, Lanzoni GMM, Assuiti LFC, Pires DEP, Ramos FRS. Gestão em saúde no Brasil: diálogo com gestores públicos e privados. Texto Contexto - Enferm [Internet]. 2014 jun; [cited 2017 oct 06]; 23(2):41725. Available from: http://www.scielo.br/scielo.php?pid=S0104 07072014000200417\&script=sci_abstract\&tlng=pt DOI: http://dx.doi. org/10.1590/0104-07072014000290013

17. Furukawa PO, Cunha ICKO. Perfil e competências de gerentes de enfermagem de hospitais acreditados. Rev Latino-Am Enferm [Internet] 2011 jan/feb; [cited 2017 oct 09]; 19(1):106-14. Available from: http:// pesquisa.bvsalud.org/bvsvs/resource/pt/bps-1004

18. Torpie K. Customer service vs patient care. Patient Exp J [Internet]. 2014; [cited 2017 oct 06 ]; 1 (2):6-8. Available from: http://pxjournal.org/journal/ vol1/iss $2 / 3$

19. Berkowitz B. The Patient Experience and Patient Satisfaction: Measurement of a Complex Dynamic. Online J Issues Nurs [Internet] 2016 jan; [cited 2017 oct 09]; 21(1):1. Available from: https://www.ncbi. nlm.nih.gov/pubmed/27852212 DOI: http://dx.doi.org/10.3912/OJIN Vol21No01Man01

20. Godil SS, Parker SL, Zuckerman SL, Mendenhall SK, Devin CJ, Asher $A L$, et al. Determining the quality and effectiveness of surgical spine care: patient satisfaction is not a valid proxy. Spine $\mathrm{J}$ [Internet]. 2013 sep; [cited 2017 oct 09]; 13(9):1006-12. Available from: https://www. thespinejournalonline.com/article/S1529-9430(13)00406-3/fulltext DOI http://dx.doi.org/10.1016/j.spinee.2013.04.008

21. Rehaman B, Husnain $M$. The impact of service quality dimensions on patient satisfaction in the private healthcare industry in Pakistan. J Hosp Med Manage [Internet]. 2018 jun; [cited 2019 jun 02]; 4(1):4 Available from: http://hospital-medical-management.imedpub.com/ the-impact-of-service-quality-dimensions-onpatient-satisfaction-inthe-private-healthcareindustry-in-pakistan.php?aid=22762 DOI: http:// dx.doi.org/10.4172/2471-9781.100048 
22. Fátima T, Malik S, Shabbir A. Hospital healthcare service quality, patient satisfaction and loyalty: an investigation in context of private healthcare systems. Int J Qual Reliab Manage [Internet]. 2018 jun; [cited 2019 jun 02]; 35(6):1195-214. Available from: https://doi.org/10.1108/ IJQRM-02-2017-0031

23. Kutney-Lee A, McHugh MD, Sloane DM, Cimiotti JP, Flynn L, Neff DF, et al. Nursing: A key to patient satisfaction. Health Affairs [Internet]. 2009; [cited 2017 oct 09]; 28(Suppl 3):669-77. Available from: http:// content.healthaffairs.org/content/28/4/w669.abstract DOI: https://doi. org/10.1377/hlthaff.28.4.w669

24. Ruthes RM, Feldman LB, Cunha ICKO. Foco no cliente: ferramenta essencial na gestão por competência em enfermagem. Rev Bras Enferm [Internet]. 2010; [cited 2017 Oct 09]; 63(2):31721. Available from: http://www.scielo.br/scielo.php?pid=S0034$71672010000200023 \&$ script=sci_abstract\&tlng=pt DOI: http://dx.doi. org/10.1590/S0034-71672010000200023

25. Fatehi Z, Ghorbani H. The causal relationship between aspects of customer capital to improve customer relationship management and increase customers' loyalty (case study: food industry of Jey industrial town in Isfahan). WALIA J [Internet]. 2015 mar; [cited 2017 oct 09] 31(S4):102-7. Available from: http://waliaj.com/archive/2015-2/specialissue-4-2015/

26. Polizer R, D'Innocenzo M. Satisfação do cliente na avaliação da assistência de enfermagem. Rev Bras Enferm [Internet]. 2006 aug [cited 2017 oct 09]; 59(4):548-51. Available from: http://www.scielo.br/ scielo.php?script=sci_arttext\&pid=S0034-71672006000400014 DOI: http://dx.doi.org/10.1590/S0034-71672006000400014

27. Freitas JS, Silva AEBC, Minamisava R, Bezerra ALQ, Sousa MRG Qualidade dos cuidados de enfermagem e satisfação do paciente atendido em um hospital de ensino. Rev Latino-Am Enfermagem [Internet]. 2014 jun; [cited 2017 oct 09]; 22(3):454-60. Available from: http://www.revistas.usp.br/rlae/article/view/86599/89510 DOI: http:// dx.doi.org/10.1590/0104-1169.3241.2437

28. Levandovski PF, Lima MADS, Acosta AM. Patient satisfaction with nursing care in an emergency service. Invest Educ Enferm [Internet]. 2015 [cited 2017 oct 09]; 33(3):473-81. Available from: http://www.scielo.org co/scielo.php?script=sci_arttext\&pid=S0120-53072015000300011 DOI: http://dx.doi.org/10.17533/udea.iee.v33n3a11

29. Martinho MJCM, Martins MMFPS, Angelo M. Escala da satisfação com a decisão em saúde: instrumento adaptado e validado para língua portuguesa. Rev Bras Enferm [Internet]. 2014 dec; [cited 2017 oct 09]; 67(6):891-7. Available from: http://www.scielo.br/scielo. php?pid=S0034-71672014000600891\&script=sci_abstract\&tIng=pt DOI: http://dx.doi.org/10.1590/0034-7167.2014670605

30. Chu SD, Khong TS. Measuring healthcare service quality in a private hospital in a developing country by tools of Victorian patient satisfaction monitor. J Hosp Adm [Internet]2018 jun; [cited 2019 may 30]; 7(5):1-7. Available from: http://dx.doi.org/10.5430/jha.v7n5p1
31. Chen Y, Liu J, Xiao S, Liu X, Tang X, Zhou Y. Model construction of nursing service satisfaction in hospitalized tumor patients. Int J Clin Exp Med [Internet]. 2014 oct; [cited 2017 oct 09]; 7(10):3621-9. Available from: https://www.ncbi.nlm.nih.gov/pubmed/25419410

32. Souza RCR, Soares E, Souza IA, Oliveira JC, Salles RS, Cordeiro CEM Educação permanente em enfermagem e a interface com a ouvidoria hospitalar. Rev Rene [Internet]. 2010; [cited 2017 oct 09]; 11(4):85-94. Available from: http://www.periodicos.ufc.br/rene/article/view/4614 DOI: http://dx.doi.org/10.15253/rev\%20rene.v11i4.4614

33. Ministério da Saúde (BR). Secretaria de Atenção à Saúde. Departamento de Regulação Avaliação e Controle de Sistemas. PNASS: Programa Nacional de Avaliação de Serviços de Saúde [Internet]. Brasília (DF): Ministério da Saúde; 2015; [cited 2017 oct 09]. Available from: http://portalarquivos.saude.gov.br/images/pdf/2015/novembro/11/ CADERNO-PNASS-2015.pdf

34. Ministério da Saúde (BR). Secretaria de Gestão Estratégica e Participativa. Departamento de Ouvidoria Geral do SUS. Manual das ouvidorias do SUS [Internet]. Brasília (DF): Ministério da Saúde; 2014 [cited 2017 oct 09]. Available from: http://bvsms.saude.gov.br/bvs/ publicacoes/manual_ouvidoria_sus.pdf

35. Fernandes FMB, Moreira MR, Ribeiro JM, Ouverney AM, Oliveira FJF, Moro MFA. Inovação em ouvidorias do SUS - reflexões e potencialidades. Ciênc Saúde Coletiva [Internet]. 2016 aug; [cited 2017 oct 09]; 21(8):2547-54. Available from: http://www.scielo.br/scielo. php?script=sci_arttext\&pid=S1413-81232016000802547\&lng=pt\&tln g=pt DOI: http://dx.doi.org/10.1590/1413-81232015218.08382015

36. Bogo PC, Bernardino E, Castilho V, Cruz EDA. O enfermeiro no gerenciamento de materiais em hospitais de ensino. Rev Esc Enferm USP [Internet]. 2015 aug; [cited 2017 oct 09]; 49(4):6329. Available from: http://www.scielo.br/scielo. php?pid=S0080 62342015000400632\&script=sci_abstract DOI: http://dx.doi. org/10.1590/S0080-623420150000400014

37. Álvarez-Hernández JG, Lavín-Verástegui J, Pedraza-Melo NA Determinando los factores del capital relacional en la interacción de cliente proveedor en MiPyMES. Entramado [Internet]. 2016 jan/jun; [cited 2017 oct 09]; 12(1):38-49. Available from: http://revistasojs. unilibrecali.edu.co/index.php/entramado/article/view/323/358 DOI: http://dx.doi.org/10.18041/entramado.2016v12n1.23134

38. Gbadeyan RA, Boachie-Mensah FO, Osemene OF. Effect of supply chain management on performance in selected private hospitals in Ilorin, Nigeria. IJEB [Internet]. 2017; [cited 2019 may 30]; 7(1):99-116. Available from: https://ideas.repec.org/a/but/ijebfa/v7y2017i1p99-116. html

39. Prakash B. Patient satisfaction. J Cutan Aesthet Surg [Internet]. 2010 [cited 2017 oct 09]; 3(3):151-5. Available from: http://www.jcasonline. com/text.asp?2010/3/3/151/74491

a This study is a clipping of the thesis: Intellectual Capital in Nursing Care Management in Hospital Organizations, defended by Ana Lúcia Arcanjo Oliveira Cordeiro, in 2015, at the Nursing School of the Federal University of Bahia, available from: http://www.repositorio.ufba.br:8080/ri/bitstream/ri/20099/1/Tese_Enf_Ana\%20 Lúcia\%20Arcanjo\%20Oliveira\%20Cordeiro.pdf 